\title{
ГИСТОХИМИЧЕСКОЕ ИЗУЧЕНИЕ КЛЕТОК КСИЛЕМЫ У IRIS SIBIRICA L. В КУЛЬТУРЕ IN VITRO*
}

\author{
(C) Л.И. Тихомирова ${ }^{* *}$, Н.Г. Базарнова, А.А. Синицына \\ Алтайский государственный университет, пр. Ленина, 61, Барнаул, 656049 \\ (Россия), e-mail: L-tichomirova@yandex.ru
}

В работе представлены данные содержания лигнина у однолетних растений-регенерантов Iris sibirica, coпоставимые с содержанием у шестилетних интактных растений. С целью выявления условий ускоренной лигнификации изучено строение побегов Iris sibirica, выросших на искусственных питательных средах, с использованием методов гистохимии.

Отмечены особенности образования ксилемы у Iris sibirica на искусственных питательных средах. Очень быстро у регенерантов развивалась сложная система, состоящая из проводящих пучков, содержащих ситовидные трубки, сосуды и трахеиды, а также сети гидроцитов. Гидроциты Iris sibirica по своему строению - это трахеиды с лигнифицированными утолщениям, но, в отличие от трахеид и сосудов ксилемы (они образуются на базе прокамбия или камбия - особых латеральных первичной или вторичной меристем), гидроциты дифференцировались из клеток постоянных тканей (подобно феллогену), которые, вероятно, на момент дифференциации обладали меристематической активностью. У Iris sibirica гидроциты мощным слоем окутывали проводящий пучок и сопровождали его вдоль побега на некоторую высоту. Вследствие образования плотной ткани из лигнифицированных трахеальных элементов у молодых регенерантов Iris sibirica определялось высокое содержание лигнина.

Изучение дифференциации элементов ксилемы в лабораторных условиях может служить образцом для нашего понимания процессов формирования древесины.

Ключевые слова: Iris sibirica L., растения-регенеранты, лигнин, ксилема, трахеальные элементы, гидроциты, интактные растения.

\section{Введение}

Деревья - главные компоненты биосферы, а древесина играет решающую роль в качестве устойчивого и возобновляемого источника сырья. Прогнозы использования главной лесной продукции предполагают, что стоимость мирового потребления изделий из древесины возрастет в реальном выражении с 597 млрд. долларов США в 2002 г. до 1,023 млрд. в 2030 г. [1]. Понимание глубинных процессов формирования древесины является обязательным условием для увеличения количества и повышения качества древесины, произведенной с учетом ее важной роли в настоящее время и для будущих поколений [2-5].

Ксилема, или древесина - водопроводящая сложная ткань сосудистых растений, состоящая из нескольких различных типов клеток, одни из которых остаются живыми, а другие отмирают и функционируют как мертвые элементы. Наиболее характерными компонентами ксилемы являются трахеальные элементы (ТЭ - трахеиды и членики сосудов).

Тихомирова Людмила Ивановна - кандидат биологических наук, заведующая отделом биотехнологии растений ЮСБС АлтГУ, e-mail: L-tichomirova@yandex.ru

Базарнова Наталья Григорьевна - доктор химических наук, профессор, заведующая кафедрой органической химии, декан химического факультета, e-mail: bazarnova@chemwood.asu.ru Синицына Анастасия Александровна - студентка, e-mail: L-tichomirova@yandex.ru
Лигнификация является одним из главных процессов, сопровождающих развитие клеток ксилемы древесных растений. Накопление лигнина в клетках растений, с одной стороны, приводит к укреплению тканей и появлению их механической прочности, с другой - является одним из наиболее значимых факторов, влияющих на производство целлюлозы и биотоплива. Поэтому процесс лигни-

\footnotetext{
*Данная статья имеет электронный дополнительный материал (приложение), который доступен читателям на сайте журнала. DOI: 10.14258/jcprm.2017011527s

А* Автор, с которым следует вести переписку.
} 
фикации активно изучается не только с целью понимания механизма биосинтеза полимера, но и получения растений с низким содержанием лигнина или с измененной структурой, чтобы обеспечить последующую легкую доступность химической деградации [6].

Формирование ксилемы, основной водопроводящей ткани растений, является предметом многих исследований. Дифференциация элементов ксилемы в лабораторных условиях является моделью для понимания процессов одревеснения клеточной стенки растений и для изучения биотехнологических способов проектирования вторичной клеточной стенки с заданными свойствами [2, 7-14]. Клетки, выращенные в искусственных условиях, являются более доступными для изучения процессов ксилемообразования (xylogenesis) [15-19]. Этот процесс изучен с использованием различных видов растений. Дифференциации ТЭ характеризуется рядом цитологических изменений в клетках: рост растяжением, отложением одревесневшей вторичной клеточной стенки и в конечном итоге программируемой смерти [2, 20-23]. Единообразие, доступность и меньшая сложность в работе делают клеточные культуры идеальными инструментами в изучении архитектуры, химического состава и молекулярной организация клеточной стенки ТЭ [18, 24-29].

В результате анализа данных источников литературы можно сделать вывод о том, что процессы ксилемообразования исследованы в основном в каллусных и суспензионных культурах травянистых и древесных видов растений. ТЭ элементы дифференцируются in vitro в виде отдельных клеток или случайных групп, не образуя сосудистую ткань, такую как in planta. Функция ТЭ и их связь с другими клетками растения не могут быть установлены в культурах клеток. Последовательность клеточных событий, связанных с дифференцировкой и формированием ТЭ, а также их лигнификации в тканевых культурах не изучена. Iris sibirica L., по нашим данным, является удобной моделью для таких исследований.

Данная работа преследует цель сделать попытку объяснения высокого содержания лигнина (на уровне шестилетних интактных растениях) в молодых регенерантах Iris sibirica (3 месяца культивирования) с точки зрения анатомии и гистологии ксилемы, с использованием методов гистохимии.

Статья входит в цикл работ, посвященных разработке биотехнологии получения альтернативного растительного сырья [30-32]. Исследования будут продолжены с целью изучения содержания и структурных характеристик лигнина, полученного в культуре ткани Iris sibirica в зависимости от условий культивирования и степени развития клеток ксилемы.

\section{Экспериментальная часть}

Растительный материал. В исследованиях использовали растения-регенеранты Iris sibirica из коллекции отдела биотехнологии растений Алтайского государственного университета (Барнаул).

Meтоды фитохимического анализа. В работе использованы общепринятые методики: методика определения лигнина с $72 \%$ серной кислотой в модификации Комарова; методика определения целлюлозы азотно-спиртовым методом; методика определения зольности методом сжигания [33].

Метод культуры ткани. Работу проводили на основе общепринятых в биотехнологии растений методов [35]. При исследовании морфогенетических потенций органов и тканей в условиях in vitro использовали стандартную питательную среду MS [36]. Для изучения процессов формирования трахеальных элементов у Iris sibirica in vitro в питательную среду вводили следующие фитогормон 6-бензиламинопурин (БАП) Sigma, в концентрации 2,5-10 мкМ. В качестве основного углевода использована сахароза в концентрации 30 г/л. Растения-регенеранты выращивали в культуральной комнате, где поддерживалась температура $20-30{ }^{\circ} \mathrm{C}, 16$-часовой фотопериод, интенсивность освещения (2000-4000 лк) и $70 \%$ относительная влажность воздуха.

Гистологические исследования. Для анатомического изучения процессов морфогенеза были проведены серии срезов. Постоянные препараты готовили по общепринятым методикам [36] в нашей модификации. Анатомо-морфологическое строение растений-регенерантов изучали в сравнении с растениямисеянцами.

Ткани и органы фиксировали в 10\% растворе формалина при комнатной температуре. В автоматической системе гистологической проводки ТРС 15 (Medite, Германия) растительный материал выдерживали по схеме: $10 \%$ раствор формалина (одна емкость) - 1 ч; Изопропилового спирта (9 емкостей) - по 1 ч 5 мин в каждой; Парафин (3 емкости) - по 1 ч 30 мин в каждой. Общее время проводки 15 ч 11 мин. 
После обработки пропитанные парафином образцы заливали в парафиновые блоки и наклеивали на кассеты. Образец резали на ротационном микротоме, полученные срезы расправляли в теплой воде 50$55^{\circ} \mathrm{C}$ и помещали на предметное стекло, на которое также наносили маркировку.

Основная базовая методика окраски гистологических препаратов на автоматическом аппарате TST44 (Medite, Германия) осуществлялась с применением гематоксилина и эозина (одновременно). Общее время окраски 18 мин. Срезы заключали в полистирол и накрывали покровными стеклами.

Для изучения готовых препаратов использовали универсальный прямой исследовательский микроскоп Axio Imager. Z1, изготовитель Carl Zeiss. Фотографии были выполнены цифровой фотокамерой AxioCam MRc 5.

Гистохимичекие исследования. Реакция с флороглюцином и соляной кислотой. Срез ткани растения помещают на предметное стекло в 1\% раствор флороглюцина в спирте, через 1 мин реактив удаляют фильтровальной бумагой, на срез наносят каплю концентрированной соляной кислоты и через 1-2 мин прибавляют каплю глицерина, далее накрывают покровным стеклом и изучают под микроскопом. Одревесневшие оболочки клеток приобретают вишневое окрашивание, интенсивность которого определяется степенью лигнификации [38].

\section{Обсуждение результатов}

Определения целлюлозы и лигнина у растений-регенерантов Iris sibirica в сравнении с интактными.

Воздушно-сухие образцы биомассы растений-регенерантов Iris sibirica анализировали на содержание золы, высокомолекулярных компонентов, экстрактивных веществ в сравнении с растениями, выращенными в полевых условиях (табл.). Методика получения экстрактивных веществ описана нами ранее [30].

Одревеснение (лигнификация) - процесс отложения в клеточной оболочке лигнина - высокополимерного аморфного, не растворимого в воде вещества фенольной природы. Инкрустируя клеточную оболочку, лигнин вытесняет находящийся между микрофибриллами целлюлозы матрикс. Интенсивность одревеснения разных слоев клеточной оболочки увеличивается по мере уменьшения в них количества целлюлозы. Наиболее сильно одревесневает серединная пластинка, которая может накапливать от 60 до $90 \%$ всего лигнина оболочки. Лигнифицированая оболочка теряет эластичность, поэтому одревеснение начинается после окончания роста клеток. Оболочка приобретает твердость, но становится более хрупкой, что увеличивает ее прочность на сжатие, но уменьшает прочность на изгиб. Такие особенности оболочек важны для клеток механических и водопроводящих тканей [39].

Анализ соотношения высокомолекулярных компонентов в нашем эксперименте выявил следующее: содержание целлюлозы в листьях интактного растения составляло 20,4\%, а в корневищах с корнями $24,4 \%$, в биомассе растений-регенерантов - 18,1\%. Вероятно, биомасса интактных растений до заготовки растительного сырья состояла из большего количества мертвых тканей, состоящих из прозенхимных клеток, которые содержат прежде всего целлюлозное волокно.

Нами определено содержание лигнина в биомассе однолетних растений-регенерантов Iris sibirica , coпоставимое с содержанием его для шестилетних интактных растений. С целью выявления условий ускоренной лигнификации необходимо детальное изучение строения побегов Iris sibirica , выросших на искусственных питательных средах, особенностей образования проводящей системы, а также количественного содержания 6-бензиламинопурина в питательных средах на процессы дифференциации элементов ксилемы.

Дифференциация клеток ксилемы у интактных растений Iris sibirica L.

Анатомическое строение интактных растений Iris sibirica изучали на срезах корневища однолетних сеянцев. На препаратах были четко видны все системы тканей, характерные для данного вида. Под эпидермисом располагаются клетки первичной коры. Далее следует одноклеточный слой эндодермы. К эндодерме плотно прилегают живые клетки перицикла, не дифференцированные в клетки склеренхимы, так как сеянец находится в стадии активного роста. Большую часть стебля (2/3) занимает сердцевина. Она состоит из паренхимы и проводящих пучков.

Анализ сырья Iris sibirica сорт Cambridge, полученного разным способом, \% на а.с.в.

\begin{tabular}{l|c|c|c|c|c}
\hline \multicolumn{2}{c|}{ Растительное сырье } & Зольность & Лигнин & Целлюлоза & Экстрактивные вещества \\
\hline интактные & листья & $11,4 \pm 0,1$ & $20,6 \pm 0,4$ & $20,4 \pm 0,9$ & 17,6 \\
растения & корневища с корнями & $16,2 \pm 0,2$ & $28,8 \pm 0,5$ & $24,4 \pm 1,1$ & 19,8 \\
\hline \multicolumn{2}{l|}{ Растения-регенеранты } & $7,6 \pm 0,1$ & $23,1 \pm 0,7$ & $18,1 \pm 0,9$ & 21,6 \\
\hline
\end{tabular}


В результате анатомических исследований корневища Iris sibirica одного года выращивания нами выявлены признаки, типичные для стебля однодольных растений. Картина прохождения пучков вдоль стебля относится к наиболее распространенному среди однодольных растений «пальмовому» типу с определенным видоизменением. Основные черты «пальмового» типа таковы. Из основания листа выходят пучки, распределяющиеся по всей толщине стебля. Более слабые, тонкие листовые следы, углубившись в стебель на небольшое расстояние от периферии, идут вертикально (параллельно продольной оси стебля). Другие пучки заходят глубже, а наиболее мощные из них приближаются к геометрической оси стебля.

В дальнейшем каждый пучок направляется вниз, становясь тоньше и постепенно приближаясь к периферии стебля. Вблизи периферии, в той области, где вертикально проходят тонкие пучки, изогнутый пучок входит в соприкосновение с листовым следом одного из ниже сидящих листьев и сливается с ним. Обилие проводящих пучков и их изогнутость отражаются на поперечных срезах их беспорядочной разбросанностью. Пучки в средине центрального цилиндра более крупные в их проводящей части и расположены более редко; сюда заходят более крупные листовые следы. По мере приближения к перициклу проводящие пучки более мелкие и более тесно расположены, что происходит вследствие того, что вблизи периферии центрального цилиндра проходят более мелкие листовые следы и подходят нижние тонкие концы более крупных пучков, изгибаясь от центра к перициклу.

При дифференцировке пучка из прокамбиального тяжа вся образовательная ткань полностью расходуется на формирование постоянных тканей и пучок становиться закрытым (Электронное приложение, рис. 1).

В зависимости от характера расположения элементов проводящей и механической ткани проводящие пучки у Iris sibirica коллатерального и амфивазального типа. Коллатерального типа пучки в корневище Iris sibirica располагаются в центральном цилиндре в области перицикла. В срединной области центрального цилиндра проходят как закрытые коллатеральные пучки, так и концентрические (амфивазальные), где ксилема окружает флоэму. На данном этапе развития сеянца Iris sibirica в проводящих пучках тяжей механической ткани (склеренхимы) мы не наблюдали (Электронное приложение, рис. 2).

Согласно исследованиям М.А. Шанидзе [40] элементы ксилемы у видов подрода Limniris представлены сосудами и трахеидами. Нами обнаружены в корневище Iris sibirica живые и мертвые трахеиды. Живые трахеиды имеют длину 500-1000 мкм, ширину 190-200 мкм, толщину стенки 33-35 мкм. Мертвые трахеиды в длину имеют продолжительность от 1000 мкм и больше, ширину - от 200 мкм и больше, толщину стенки - 45-47 мкм. Продольные стенки их утолщены неравномерно, содержат точечные перфорации - щелевидные простые не окаймленные поры. Сосуды имеют диаметр меньше, чем у трахеид, в среднем 125-140 мкм, но значительно длиннее. По типу утолщения клеточной стенки сосуды можно отнести к спиральным. Поры окаймленные (Электронное приложение, рис. 3).

Трахеиды - прозенхимные клетки длиной в несколько миллиметров, шириной в десятые и сотые доли миллиметра. Взрослые трахеиды представляют собой мертвые клетки с утолщенными лигнифицированными (одревесневшими) оболочками, несущими поры, часто окаймленные. Фильтрация растворов из одной трахеиды в другую происходит через эти поры. Формируются трахеиды из прокамбиальных пучков верхушечной меристемы, а также из камбия. Для них характерен интрузивный (скользящий) рост, когда одна из трахеид внедряется своим заостренным концом между другими трахеидами. Образуется сплошная масса плотно прилегающих друг к другу трахеид, заполняющих большую часть объема осевых органов растений. Трахеиды передают растворы не только в вертикальном, но и в горизонтальном направлении, в лежащие рядом проводящие и паренхимные клетки. Поэтому боковые стенки у них водопроницаемы. В то же время для трахеид характерны утолщения различной формы - кольчатые, спиральные, сетчатые, лестничные и точечные. Такое утолщение оболочки не по всей ее поверхности, а в отдельных участках имеет огромное биологическое значение. При относительно экономном расходовании органического вещества водопроводящие элементы оказываются устойчивы к сжатию и растяжению и в то же время проницаемы (в поперечном направлении) [41].

\section{Клеточная дифференцииция и лигнификациия ксилемы у Iris sibirica in vitro}

При анатомических исследованиях на продольном срезе побега Iris sibirica, выросшего на питательной среде MS, содержащей 2,5 мкМ БАП, были хорошо различимы системы тканей. В апикальной части побега наблюдали почку и примордии листьев, в паренхимных клетках первичной коры много крахмала. 2/3 объема побега занимает центральный цилиндр (см. рис. 1a). Растения Iris sibirica в культуре ткани растут в течение всей своей жизни, не прерываясь на период зимнего покоя. Рост происходит в определенных, весьма многочисленных участках тела растения. Для Iris sibirica характерны верхушечные меристемы: точка роста основного побега, точки роста пазушных и адвентивных побегов, точки роста адвентивных корней. Верхушечная 
меристема корневища состоит из плотно сомкнутых клеток с протопластом, содержащим крупное ядро. Оболочка клеток тонкая на всем протяжении. Клетки меристемы делятся и дают начало основным, преимущественно паренхимным, тканям, несущим функции накопления и хранения запасов.

Прокамбий, дифференцирующийся среди меристемы, представляет собой тяжи, состоящие из клеток, отличающихся от окружающих их основной меристемы меньшими поперечным и большими продольными размерами. Прокамбиальные тяжи дают начало проводящим пучкам. Тяж и цилиндр прокамбия полностью дифференцируются в постоянные ткани. Таким образом, формообразование в верхушечной части побега Iris sibirica in vitro проходит аналогично таковому in planta.

При культивировании на питательных средах каждые 30 дней побеги ириса пересаживали на свежие питательные среды. При этом скальпелем счищали мертвые клетки у основания побега. Первая реакция на поранение - формирование защитной пленки и раневой пробки, предохраняющих живые ткани регенерантов. Как отмечает О.А. Чурикова, в ходе анализа морфогенетических процессов у лилейников и хосты in vitro в ряде случаев наряду с пленкой из остатков разрушенных клеток и клеточного сока наблюдалось образование раневой пробки, представляющей собой защитную ткань особого типа - ярусную пробку, характерную для других однодольных [42].

У побегов Iris sibirica защитная ткань особого типа возникала в результате многократных делений паренхимных клеток. Эти деления, периклинальные по направлению, повторялись несколько раз до тех пор, пока не образовывался слой толщиной 3-8 клеток. Стенки паренхимных клеток при этом утолщались. Делящиеся клетки дифференцировались впоследствии в клетки пробки [42].

Как указывает К. Эсау [41], пробка, образующаяся без участия инициального слоя, или филлогена, получила название ярусной пробки, так как цепочки слагающих ее клеток образуют тангентальные полосы. Поскольку процесс формирования пробки происходит в центростремительном направлении, между клетками пробки могут оказаться включенными и неопробковевшие клетки (рис. 1б).

Ткани и клетки, всасывающие воду с растворенными органическими веществами, имеются в течение всей жизни у растений, относящихся к числу паразитов, сапрофитов и насекомоядных, а у растений автотрофных - в стадии проростков, использующих питательные запасы семени [43].

Наряду с защитными, базальные клеточные слои являются тканями всасывания у Iris sibirica in vitro. Так как растения-регенеранты не используют корни для поглощения воды и растворенных веществ, всасывание происходит клетками покровных тканей, соприкасающихся с питательной средой. По своим функциям раневая пробка регенерантов схожа с веламеном, своеобразной тканью, покрывающей корни эпифитов и некоторых других растений, приспособленных к жизни на периодически пересыхающих субстратах. Наличие веламена характерно для многих видов растений семейств Орхидные (фаленопсис) и Ароидные (антуриумы, монстеры и сциндапсусы). Веламен образуется в результате многократных продольных делений клеток эпидермиса, от ризодермы отличается многослойностью. Протопласт веламена отмирает и поэтому всасывает воду не осмотическим, а капиллярным путем [41].

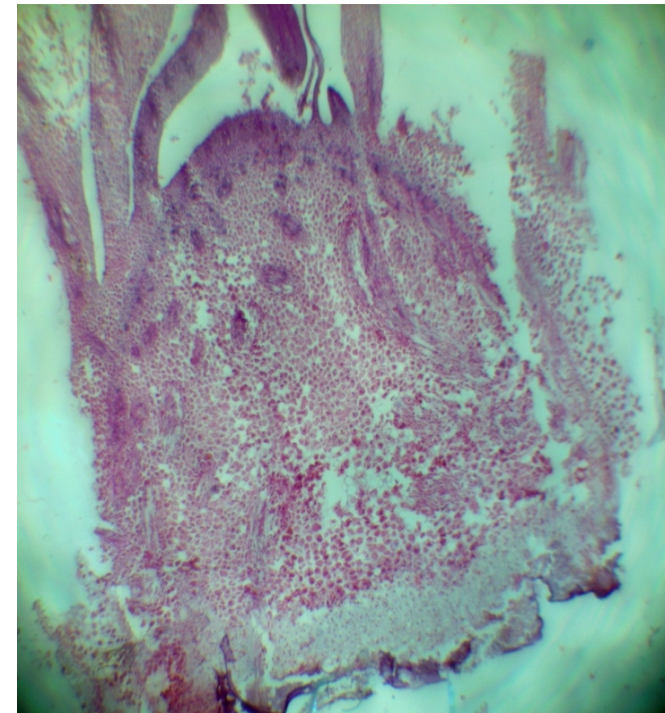

$a$

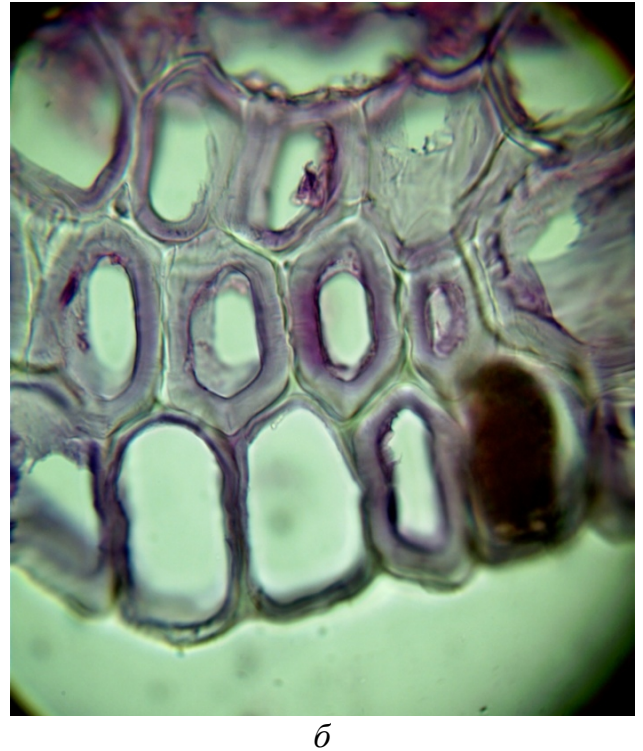

$\sigma$

Рис. 1. Продольный срез корневища растения-регенеранта Iris sibirica (увел.×100) (a), клетки раневой пробки (увел.×400) (б) 
Поглощение корнями воды и минеральных веществ - наиболее важная их функция. Вода, поглощаемая корневым волоском, проходит сложный путь по живым клеткам паренхимы корня и только после этого попадает вместе с растворенными в ней веществами в элементы ксилемы, находящейся в центральном цилиндре. У регенерантов Iris sibirica мертвые клетки раневой пробки всасывают воду, которая по живым клеткам с утолщенными стенками проходит к окончаниям сосудистых пучков. Проводящие пучки входят в слой основной паренхимы с утолщенными клеточными стенками (склерохимоидной ткани) и слепо заканчиваются отверстиями проводящей системы. Вода и растворенные в ней вещества передвигаются к другим органам и клеткам и образуют восходящий ток, который идет по трахеидам и сосудам проводящего пучка.

Российский ученый В.Г. Александров особые трахиальные элементы, формирующиеся в эксплантах, в культуре in vitro определил как гидроциты. Гидроциты принадлежат к широко распространенному типу водоносных элементов и отличаются от анатомических элементов других типов тем, что в них сравнительно долго сохраняются клеточные ядра, хотя утолщения их оболочек одревесневшие. Гидроциты способствуют более быстрой подаче воды, чем обычные паренхимные клетки экспланта, в результате чего в экспланте формируется полноценная проводящая система [44].

По мнению О.А. Чуриковой, одной из характерных особенностей гистологической дифференциации при регенерации растений в культуре in vitro является, в частности, развитие гидроцитной системы. Формирование такой васкулярной системы наблюдается и в культивируемых эксплантах органов разной морфологической природы. Посредством ее происходит перемещение эргопластических веществ и гормональных регуляторов роста, проведение их в очаги меристематической активности. Гидроцитные узлы появляются вслед за образованием очагов меристемы, часто выступая в качестве центров дальнейшей морфологической дифференциации, или васкулярные элементы формируются уже при первых делениях инциальных клеток, на стадии полиад, стимулируя деление прилегающих к ним клеток с последующим образованием побеговых конусов. Вышеуказанные процессы могут идти и параллельно. Наконец, васкулярные элементы возникают также в основании адвентивных побегов [42]. Трахеальные элементы, образуемые в регенерантах, представляют собой клетки с сетчато-полосчатыми вторичными утолщениями клеточной стенки и могут рассматриваться как адвентивные трахеиды[45]. Дифференциация трахеальных элементов характеризуется утолщением клеточной стенки, лигнификацией и смертью клеток. Узорчатые клеточные стенки с вторичным утолщением состоят в основном из полисахаридов (микрофибрилл целлюлозы и гемицеллюлоз) и лигнина [46]. Эти компоненты способствуют большей прочности и стойкости к деградации. Отложение в клеточной стенке полимеров предотвращает распад ксилемы под высоким давлением, создаваемым транспортировкой жидкости [47] и позволяет ТЭ выдержать отрицательное давление, создаваемое в ходе транспирации.

Поперечные и продольные срезы растений-регенерантов Iris sibirica мы использовали в реакции с флороглюцином и соляной кислотой. Одревесневшие оболочки клеток приобретали вишневое окрашивание, интенсивность которого определялась степенью лигнификации. В наших исследованиях побегов Iris sibirica, выросших на искусственных питательных средах, отмечены особенности образования проводящей системы, в частности ксилемы. От основания побегов (места соприкосновения ткани и питательной среды) тянулись проводящие пучки, содержащие в своем составе сосуды, трахеиды и гидроциты (см. рис. 2).

$\mathrm{У}$ растений-регенерантов Iris sibirica гидроциты мощным слоем окутывали проводящий пучок и сопровождали его вдоль побега на некоторую высоту. В связи с этим базальная часть побега была пронизана массой гидроцитных тяжей, а в апикальной части гидроцитов было значительно меньше. Дифференциация паренхимных клеток в гидроциты происходит вблизи проводящих пучков и в основании побегов (см. рис. 3).

Дифференциация гидроцитов. Клетки паренхимы центрального цилиндра и первичной коры растений-регенерантов и интактных растений Iris sibirica имеют сопоставимый размер в пределах 350,0 мкм. Но клетки паренхимы регенерантов средней части побегов плазмолизируются и протопласт отходит от клеточной стенки, структура будущей вторичной оболочки оказывается различимой в наружной части протопласта (рис. 4). В базальной части побега стенки живых клеток паренхимы лигнифицируются неравномерно с образованием простых пор. У гидроцитов Iris sibirica особый, очень распространенный тип сетчатого утолщения представлен в виде точечной или пористой оболочки. Она формируется в тех случаях, когда толстые перемычки сетки занимают большую часть оболочки, а ячеи сетки, т. е. тонкие участки оболочки, очень мелкие (Электронное приложение, рис. 4). 


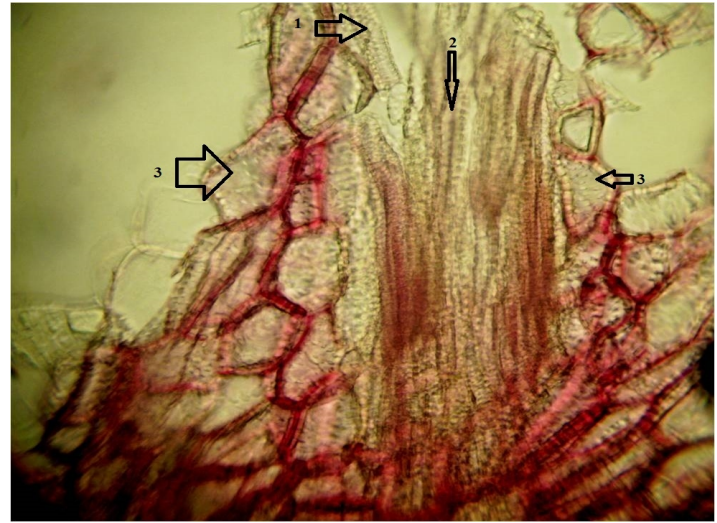

a

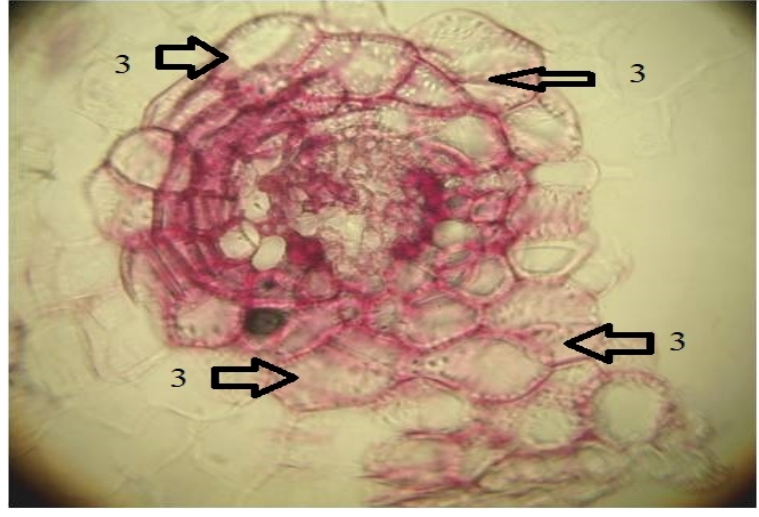

б

Рис. 2. Срез проводящего пучка (реакция с флороглюцином и соляной кислотой): продольный $(a)$, поперечный (б), (увел.×1000): 1 - сосуды, 2 - трахеиды, 3 - гидроциты

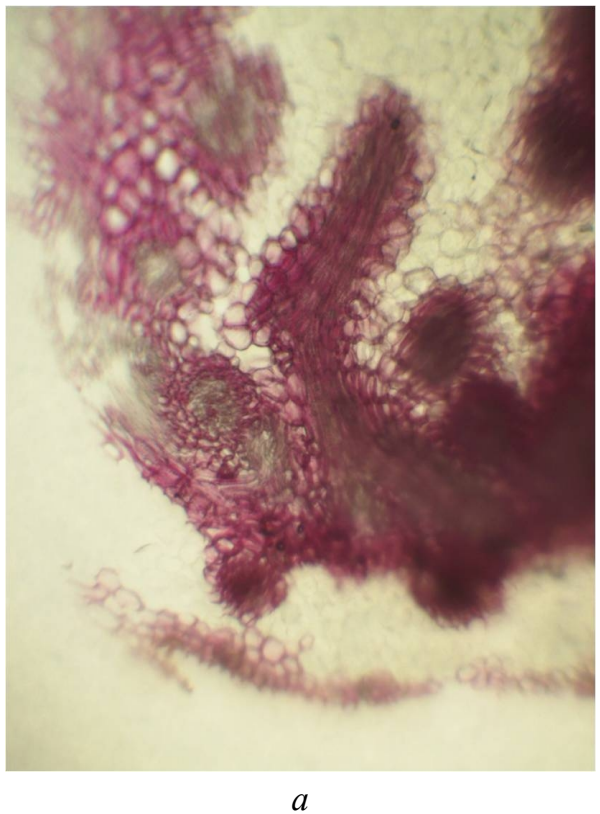

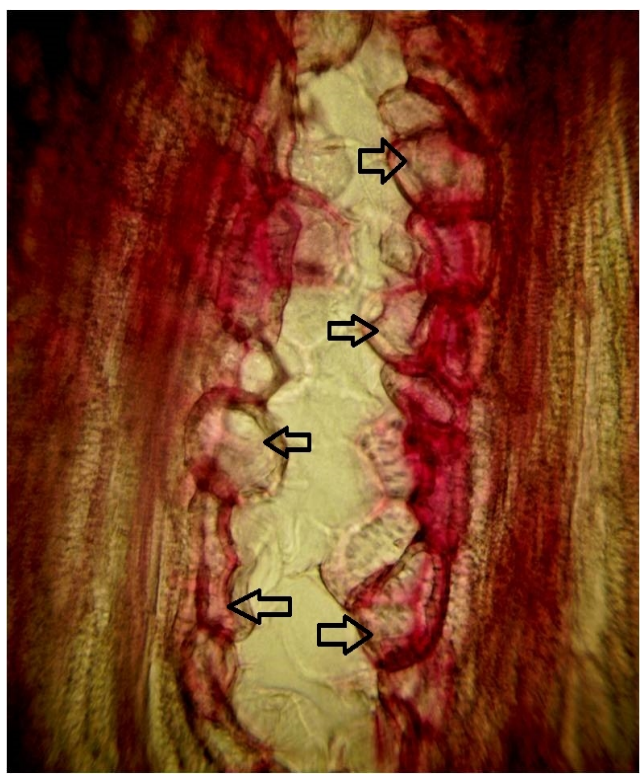

$\sigma$

Рис. 3. Продольный срез проводящего пучка в окружении гидроцитов (реакция с флороглюцином и соляной кислотой): увел. $\times 100(a)$; увел. $\times 1000($ б)

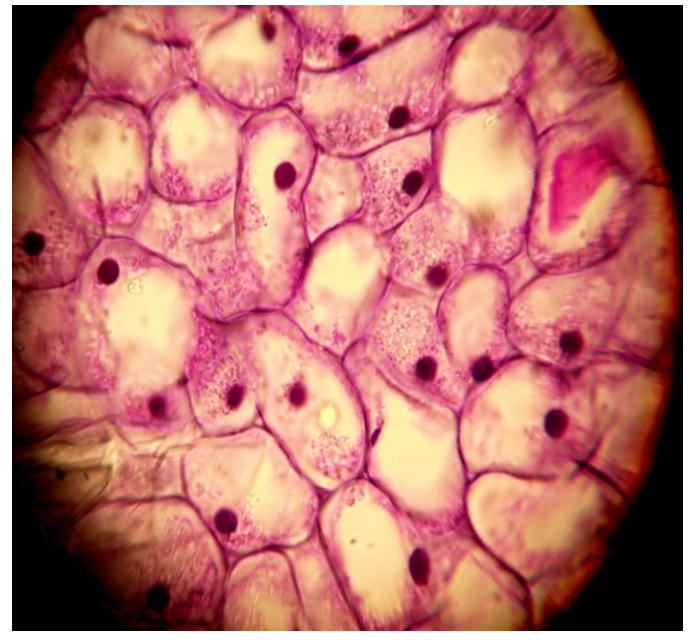

$a$

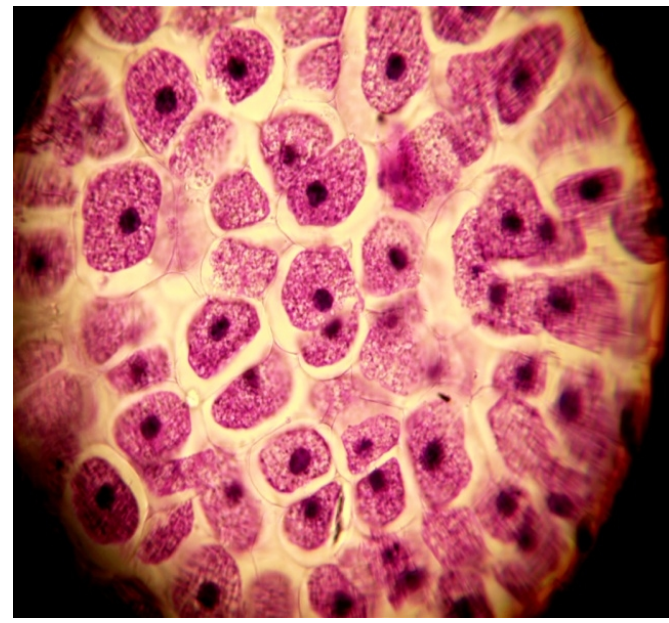

$\sigma$

Рис. 4. Клетки паренхимы центрального цилиндра средней части побегов: интактного растения $(a)$, растения-регенеранта (увел.×1000) (б) 
Влияние содержания 6-бензиламинопурина (БАП) на дифференцฺиацию клеток ксилемы у растенийрегенерантов Iris sibirica $L$.

На этапе собственно микроразмножения для Iris sibirica были заложены варианты опыта с различной концентрацией БАП $(2,5,5,0,7,5$ и 10,0) в питательных средах. Анатомические исследования препаратов побегов, выращенных на разных концентрациях БАП, показали определенные отличия в гистологическом плане (рис. 5). На питательных средах, содержащих 1,0-5,0 мкМ БАП, побеги морфологически были не изменены. При анатомическом исследовании было выявлено следующее: эпидерма представляла слой клеток различной формы, плотно сомкнутых, в субэпидермальном слое располагались клетки колленхимы, первичная кора состояла из 10-12 клеточных слоев. В районе перицикла отмечали клетки склеренхимы. Цитоплазма клеток слабо окрашена, включений в клетках не отмечено. Паренхимные клетки разной формы и размеров. Вдоль проводящих пучков располагаются клетки с утолщенными лигнифицированными стенками с перфорациями, образуя с элементами ксилемы и флоэмы проводящую систему корневища. Так как основание корневища находится на питательной среде, гидроцитов больше именно в этой части корневища. Логично было предположить, что элементы ксилемы и флоэмы не обеспечивают корневище питательными веществами в достаточном количестве, а гидроциты играют определенную роль в этом процессе.

При введении 7,5 мкМ БАП в питательные среды наблюдали сильно плазмолизированные клетки паренхимы центрального цилиндра и первичной коры побега Iris sibirica. Основную площадь в сечении корневища занимал центральный цилиндр с гипертрофированной проводящей тканью. Вероятно, под влиянием токсического действия высоких концентраций гормонов происходило патологическое разрастание трахеальных элементов вокруг проводящих пучков, приводящее к угнетению последних и гибели клеток паренхимы центрального цилиндра. Первичная кора на сечении корневища у таких побегов была представлена в виде рыхлого слоя клеток (см. рис. 6).

При концентраций БАП 7,5-10,0 мкМ недоразвитие элементов ксилемы и флоэмы компенсируется массовым формированием гидроцитной системы побега. При 10 мкМ БАП, по всей видимости, токсическое действие высоких концентраций БАП и недостаток ауксинов проявляется у регенерантов, прежде всего в слабом развитии проводящих тканей. Возможно, при активных регенерационных процессах связанных с действием данных концентраций БАП, трахеи и ситовидные трубки адвентивных побегов не успевают формироваться, и гидроциты сопровождают проводящие пучки, осуществляя таким образом связь с материнским корневищем.

В том случае, когда концентрация БАП выше 10,0 мкМ, у Iris sibirica подавлено развитие всей проводящей системы. У регенерантов проводящие пучки были в незначительном количестве, гидроциты не выявлены, как следствие, побегообразовательной деятельности мы не наблюдали. Токсическое действие гормона проявлялось в изменении морфологии побега, угнетении развития, частичном некрозе листьев и полной гибели.

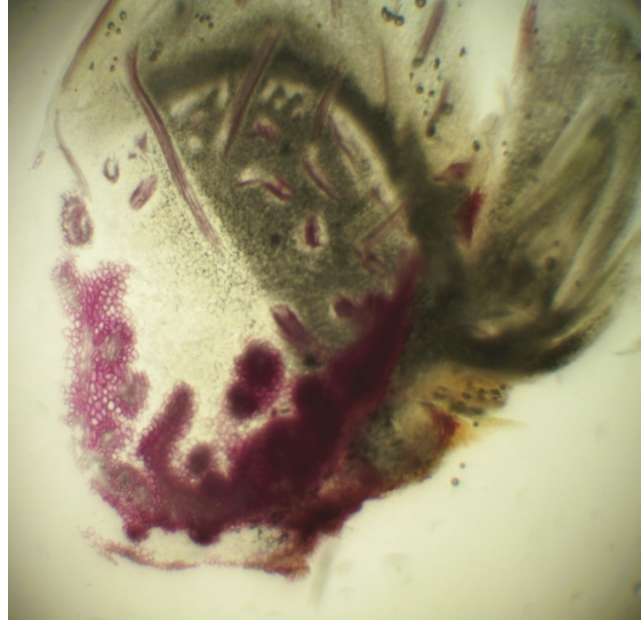

a

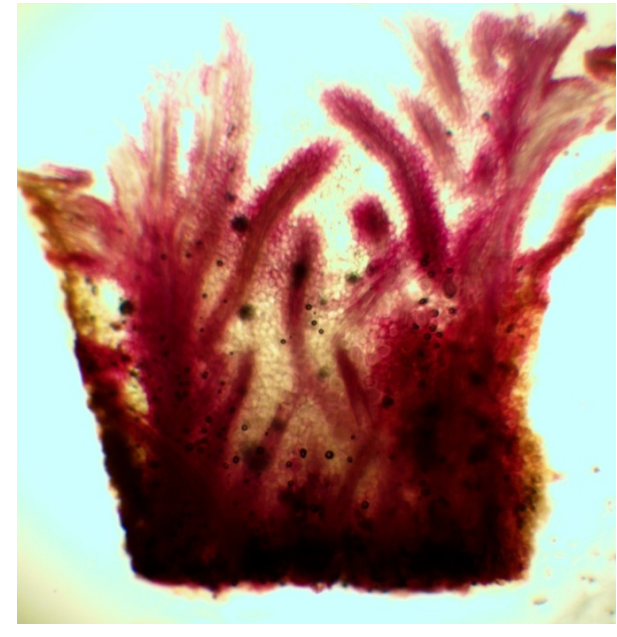

б

Рис. 5. Продольный срез побега (реакция с флороглюцином и соляной кислотой): выращенного на питательной среде с 2,5 мкМ БАП (a); выращенного на питательной среде с 5,0 мкМ БАП (увел.×1000) (б) 


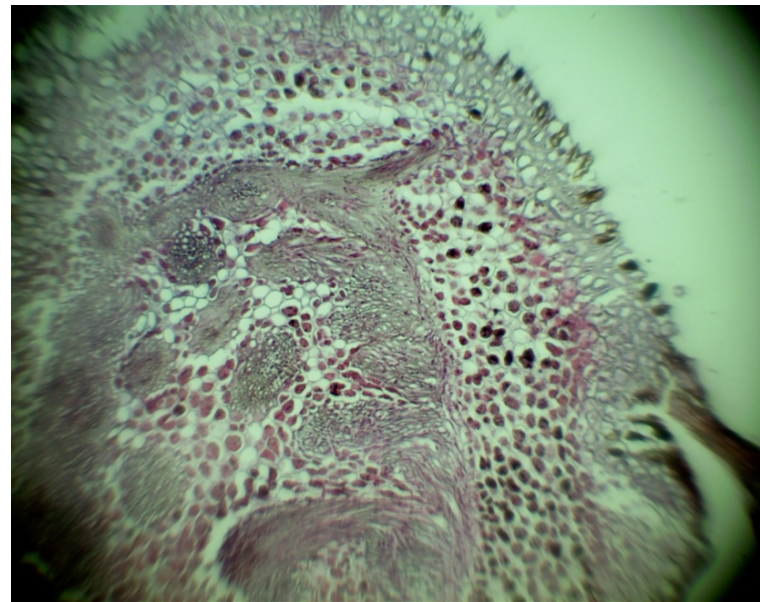

$a$

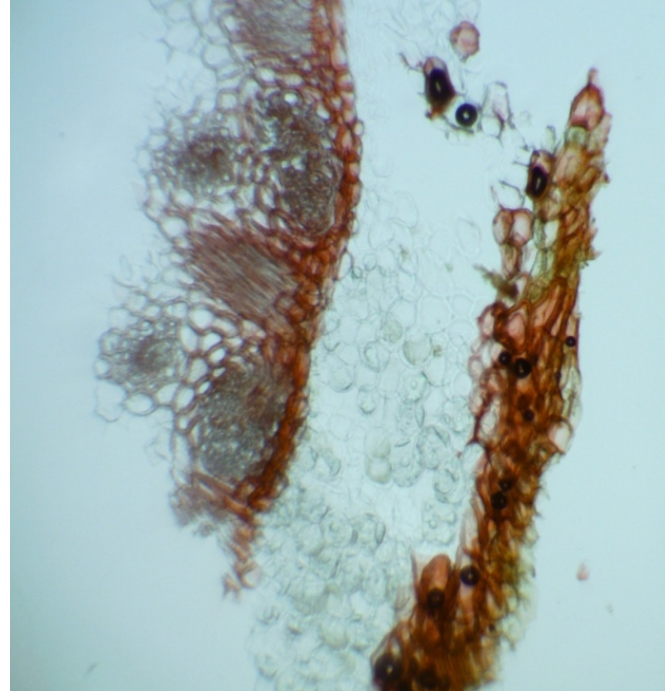

б

Рис. 6. Поперечный срез побега: выращенного на питательной среде с 7,5 мкМ БАП (a); реакция с флороглюцином и соляной кислотой (б)

Регулирование развития проводящей системы является одной из основных нерешенных проблем современной биологии развития растений. По нашему мнению, анатомическое строение растений Iris sibirica вкультуре in vitro больше схоже со строением растений засушливых мест обитания. Проводящие пучки коллатеральные, с большим количеством склеренхимы, обкладки проводящих пучков расположены часто прямо в паренхиме. Вероятно, это связано с концентрацией солей, растворенных в питательной среде MS. При этом влажность воздуха в сосуде культивирования достаточно высокая (устьица не закрываются). Процесс формирования пробки и гидроцитов на базальном конце побега растения-регенеранта Iris sibirica инициирован не только поранением вследствие очищения некротизированных участков при пересадке каждые 30 суток, но и условиями выращивания на искусственных питательных средах. Концентрация макросолей в среде, по-видимому, оказывает влияние как гипертонический раствор, вынуждая содержимое паренхимных клеток в центральной части побега плазмолизироваться, а по мере приближения к базальному концу побега одревесневать клеточную стенку с последующей гибелью клетки.

Так как у Iris sibirica мы наблюдали дифференциацию ТЭ в растении-регенеранте, содержащем все (кроме корней) органы и ткани, рассматривать формирование ксилемы вне связи с другими процессами морфогенеза представляется необоснованным. Известно, что цитокинины позитивно влияют на активность апикальных меристем побега, формирование примордиев листьев и развитие сосудов побега. Но физиологический эффект цитокининов зависит от их концентрации и может быть отрицательным. У растений высокий уровень цитокининов подавляет пролиферацию и приводит к гибели клеток. Введение в питательные среды цитокининов необходимо для заложения и формирования адвентивных и пазушных побегов. Повышение количества гормона ведет к массовому процессу побегообразования, а это в свою очередь определяет дополнительную нагрузку на проводящую систему материнского побега. Определенное количество проводящих пучков генетически закреплено у видов. Процесс формирования пучка требует определенного времени, а адвентивные побеги закладываются каждые 30 суток (на этом основано микроклональное размножение), и им необходимы питательные вещества и вода для развития. Возможно, наиболее оптимальным для растения в данном случае явилось формирование гидроцитов. Очень быстро у регенерантов развивается сложная система, состоящая из проводящих пучков, содержащих ситовидные трубки, сосуды и трахеиды, а также сети гидроцитов.

По своему строению гидроциты - это трахеиды с утолщениями (спиральными, кольчатыми, точечными), но, в отличие от трахеид и сосудов ксилемы (они образуются на базе прокамбия или камбия - особых латеральных первичной или вторичной меристем), гидроциты дифференцируются из клеток постоянных тканей (подобно феллогену), которые, вероятно, на момент дифференциации обладали меристематической активностью. Гидроциты не являются результатом деятельности апикальных меристем. Они способствуют проведению метаболитов в области гистогенеза и органогенеза и образуют «мостики» между тканями материнского побега и клетками адвентивных побегов и корней, которые формируются в точках морфогенеза из 
апикальных меристем. Это очень важно. Таким образом проявляются механизмы морфогенеза - как ответ на биохимический состав питательной среды и физиологическое состояние материнского растения.

Но процесс размножения гидроцитов не может быть бесконечным. Под влиянием высоких концентраций БАП наступает такой момент, когда их количество становиться избыточным, и они заполняют весь центральный цилиндр, вытесняя паренхиму и угнетая проводящие пучки. Побег испытывает недостаток в воде и питании, внешне выглядит угнетенным с пониженным тургором тканей. Растение перестает размножаться и в конечном итоге гибнет.

У растений-регенерантов Iris sibirica лигнифицированные трахеальные элементы образуют довольно плотную ткань, переплетаясь друг с другом в узлах. В связи с этим содержание лигнина у однолетних растений-регенерантов сопоставимо с содержанием у шестилетних интактных растений.

\section{Bbыводbl}

1. Высокое содержание лигнина, на уровне шестилетних интактных растений в молодых регенерантах Iris sibirica, определялось вследствие образования плотной ткани из лигнифицированных трахеальных элементов.

2. Гистохимическое изучение строения побегов Iris sibirica, выросших на искусственных питательных средах, выявило особенности образования ксилемы. У регенерантов развивалась сложная система, состоящая из проводящих пучков, содержащих ситовидные трубки, сосуды и трахеиды, а также сети гидроцитов.

4. Содержание 6-бензиламинопурина (БАП) в питательной среде оказывало стимулирующее влияние на дифференциацию гидроцитов у растений-регенерантов Iris sibirica L.

5. Дальнейшее изучение особенности дифференциации и лигнификации ксилемы у регенерантов Iris sibirica L. даст возможность продвинуться в нашем понимании биохимических процессов формирования древесины.

\section{Список литературы}

1. Turner J.A., Buongiorno J., Maplesden F., Zhu S., Bates S., Li R. World Wood Industries Outlook // Forest Research Bulletin. 2006. Vol. 230. Pp. 2005-2030. I

2. Turner S., Gallois P., Brown D. Tracheary Element Differentiation // Annu. Rev. Plant Biol. 2007. Vol. 58. Pp. $407-433$.

3. Fukuda H. Plant tracheary elements // Encyclopedia of Life Sciences. 2010. Pp. 1-5.

4. Bollhöner B., Prestele J., Tuominen H. Xylem cell death: emerging understanding of regulation and function // Journal of Experimental Botany. 2012. Vol. 63. N3. Pp. 1081-1094.

5. Oda Y., Fukuda H. Secondary cell wall patterning during xylem differentiation // Current Opinion in Plant Biology. 2012. Vol. 15. N1. Pp. 38-44.

6. Антонова Г.Ф., Железниченко Т.В., Стасова В.В. Лигнификация каллуса сосны обыкновенной как реакция на условия культивирования и состав питательной среды // Сибирский лесной журнал. 2014. №6. С. 46-59.

7. Preeti Dahiya. Role of death in providing lifeline to plants // Trends in Plant Science. 2003. Vol. 8. Pp. $462-465$.

8. Pesquet E., Ranocha P., Legay S., Digonnet C., Barbier O., Pichon M., Goffner D. Novel Markers of Xylogenesis in Zinnia Are Differentially Regulated by Auxin and Cytokinin1,[W] // Plant physiol. 2005. Vol. 139. Pp.1821-1839.

9. Oda Y., Hasezawa S. Review Cytoskeletal organization during xylem cell differentiation // Plant Tissue Cult. 2006. Vol. 119. N3. Pp. 167-177.

10. Pyo H., Demura T., Fukuda H. Tere; a novel cis-element responsible for a coordinated expression of genes related to programmed cell death and secondary wall formation during differentiation of tracheary elements // Plant J. 2007. Vol. 51. N6. Pp. 955-965.

11. Ibañes M., Fàbregas N., Chory J., Caño-Delgado A.I. Brassinosteroid signaling and auxin transport are required to establish the periodic pattern of Arabidopsis shoot vascular bundles // Proc Natl Acad Sci USA. 2009. Vol. 106. N32. Pp. 13630-13635.

12. Kwon S.I., Cho H.J., Park O.K. Role of Arabidopsis RabG3b and autophagy in tracheary element differentiation // Autophagy. 2010. Vol. 6. N8. Pp. 1187-1189

13. Kwon S.I., Cho H.J., Jung J.H., Yoshimoto K., Shirasu K., Park O.K. The Rab GTPase RabG3b functions in autophagy and contributes to tracheary element differentiation in Arabidopsis. // Plant J. 2010. Vol. 64. N1. Pp. 151-164.

14. Fàbregas N., Ibañes M., Caño-Delgado A.I. A systems biology approach to dissect the contribution of brassinosteroid and auxin hormones to vascular patterning in the shoot of Arabidopsis thaliana // Plant Signal Behav. 2010. Vol. 5. N7. Pp. 903-906.

15. Milioni D., Sado P.E., Stacey N.J., Roberts K., McCann M.C. Early gene expression associated with the commitment and differentiation of a plant tracheary element is revealed by cDNA-amplified fragment length polymorphism analysis // Plant Cell. 2002. Vol. 14. N11. Pp. 2813-2824.

16. Demura T., Tashiro G., Horiguchi G., Kishimoto N., Kubo M., Matsuoka N., Minami A., Nagata-Hiwatashi M., Nakamura K., Okamura Y., Sassa M., Suzuki S., Yazaki J., Kikuchi S., Fukuda H. Visualization by comprehensive microarray analysis 
of gene expression programs during transdifferentiation of mesophyll cells into xylem cells // Proceedings of the National Academy of Sciences of the United States of America, 2002. Vol. 99. N24. Pp. 15794-15799.

17. Möller R., Koch G., Nanayakkara B., Schmitt U. Lignification in cell cultures of Pinus radiata: activities of enzymes and lignin topochemistry // Tree Physiology. 2005. Vol. 26. N2. Pp. 201-210.

18. Kubo M., Udagawa M., Nishikubo N., Horiguchi G., Yamaguchi M., Ito J., Mimura T., Fukuda H., Demura T. Transcription switches for protoxylem and me taxylem vessel formation // Genes Dev. 2005. Vol. 19. Pp. 1855-1860.

19. Devillard C., Walter C. Formation of plant tracheary elements in vitro - a review // New Zealand Journal of Forestry Science. 2014. Vol. 44. Pp. 2-14.

20. Fukuda H. Xylogenesis: initiation, progression, and cell death // Annual Review of Plant Physiology and Plant Molecular Biology. 1996. Vol. 47. N1. Pp. 299-325.

21. McCann M.C. Tracheary element formation: Building up to a dead end // Trends in Plant Science. 1997. Vol. 2. N9. Pp. 333-338.

22. Denton D., Nicolson S., Kumar S. Cell death by autophagy: facts and apparent artefacts // Cell Death and Differentiation. 2012. Vol. 19. N1. Pp. 87-95.

23. Kuriyama H., Fukuda H. Developmental programmed cell death in plants // Current Opinion in Plant Biology. 2002. Vol. 5. N6. Pp. 568-573.

24. McCabe P.F., Leaver C.J. Programmed cell death in cell cultures // Plant Molecular Biology. 2000. Vol. 44. N3. Pp. 359-368.

25. Fukuda, H. Signals that control plant vascular cell differentiation // Nature Reviews Molecular Cell Biology. 2004. Vol. 5. N5. Pp. 379-391.

26. Kohlenbach H.W., Schöpke C. Cytodifferentiation to tracheary elements from isolated mesophyll protoplasts of Zinnia elegans // Naturwissenschaften. 1981. Vol. 68. Pp. 576-577.

27. Roberts A.V., Walker S., Horan I., Smith E.F., Mottley J. The effect of growth retardants, humidity and lighting at Stage III on Stage IV of micropropagation inchrysanthemum and rose // Acta Hortic. 1992. Vol. 319. Pp. 153-158.

28. Lacayo C.I., Malkin A.J., Holman H.Y.N., Chen L., Ding S.Y., Hwang M.S., Thelen M.P. Imaging cell wall architecture in single Zinnia elegans tracheary elements // Plant Physiology. 2010. Vol. 154. N1. Pp. 121-133.

29. Höfte H. Plant cell biology: how to pattern a wall // Current Biology. 2010. Vol. 20. N1. Pp. 450-452.

30. Базарнова Н.Г., Ильичёва Т.Н., Тихомирова Л.И., Синицына А.А. Скрининг химического состава и биологической активности Iris sibirica L. сорт Сambridge // Химия растительного сырья. 2016. №3. С. 49-57.

31. Тихомирова Л.И., Ильичёва Т.Н., Базарнова Н.Г., Сысоева А.В. Способ получения лекарственного растительного сырья лапчатки белой (Potentilla alba L.) в условиях гидропоники // Химия растительного сырья. 2016. №3. C. 59-66.

32. Базарнова Н.Г., Тихомирова Л.И., Фролова Н.С., Микушина И.В. Выделение и анализ экстрактивных веществ лапчатки белой (Potentilla alba L.), выращенной в различных условиях // Химия растительного сырья. 2016. №1. С. 43-51.

33. Оболенская А.В. Лабораторные работы по химии древесины и целлюлозы: учебное пособие. М., 1991. 320 с.

34. Музычкина Р.А., Корулькин Д.Ю., Абилов Ж.А. Технология производства и анализ фитопрепаратов. Алматы, $2011.360 \mathrm{c}$.

35. Калинин Ф.Л., Сарнацкая В.В., Полищук В.Е. Методы культуры в физиологии и биохимии растений. Киев, 1980. $488 \mathrm{c}$.

36. Murashige T., Skoog F. A Revised Medium for Rapid Growth and Bioassaya with Tobacco Tissue cultures // Physiol. Plant. 1962. Vol. 15. N4. Pp. 473.

37. Барыкина Р.П., Веселова Т.Д., Девятов А.Г. Справочник по ботанической микротехнике. Основы и методы. М., 2004. $312 \mathrm{c}$.

38. Дженсен У. Ботаническая гистохимия. М., 1965. 377 с.

39. Клеточная оболочка растительной клетки. [Электронный ресурc]. URL: http://www.activestudy.info/kletochnayaobolochka-rastitelnoj-kletki/.

40. Шанидзе М.А. Анатомический анализ вегетативных органов грузинских представителей рода Iris как материал для познания филогенеза рода : автореф. дис. ... канд. биол. наук. Тбилиси, 1955. 25 с.

41. Эсау К. Анатомия растений. М., 1969. 564 с.

42. Чурикова О.А. Некоторые закономерности морфогенеза in vitro // Биотехнология как инструмент сохранения биоразнообразия растительного мира. Сборник статей по материалам II Всероссийской научно-практической конференции. Волгоград, 2008. С. 276-282.

43. Раздорский В.Ф. Архитектоника растений. М., 1955. 402 с.

44. Александров В.Г. Анатомия растений. М., 1966. 431 с.

45. Roberts L.W. The initiation of xylem differentiation // Bot. Rev. 1969. Vol. 35. N3. Pp. 201-250.

46. Wagner A., Donaldson L., Ralph J. Lignification and Lignin Manipulations in Conifers // Advances in Botanical Research. 2012. Vol. 61. Pp. 37-76.

47. Roberts K., McCann M.C. Xylogenesis: The birth of a corpse // Current Opinion in Plant Biology. 2000. Vol. 3. N6. Pp. 517-522.

Поступило в редакциию 10 октября 2016 г. 
Tikhomirova L.I.*, Bazarnova N.G., Sinitsyna A.A. HISTOCHEMICAL STUDY XYLEM CELLS HAVE IRIS SIBIRICA L. IN CULTURE IN VITRO

Altai State University, pr. Lenina, 61, Barnaul, 656049 (Russia), e-mail: L-tichomirova@yandex.ru

This paper presents the data content of the lignin from annual plants-regenerants Iris sibirica is comparable to the content of a 6-year-old intact plants. With the aim of identifying conditions of accelerated lignification studied the structure of the shoots of Iris sibirica, grown on artificial nutrient media, using the methods of histochemistry.

Peculiarities of the formation of the xylem from Iris sibirica on artificial nutrient media. Very quickly regenerants developed a complex system consisting of conducting bundles containing sieve tubes, vessels and tracheids, and as a network of gidrozit. Hydrocity Iris sibirica in its structure is tracheids with significiance the swelling, but, in contrast to tracheids and vessels of xylem (they are formed on the basis of procube or cambium - lateral special primary or secondary meristem), hydrocity differentiated from the cells of permanent tissues (like phellogen), which probably at the time of differentiation possessed meristematic activity. From Iris sibirica hydrocity thick layer envelops the conductive beam and accompanied him along the escape at a certain height. Due to the formation of the thick fabric of significiance tracheal elements, young regenerants Iris sibirica was high lignin content.

The study of the differentiation of xylem elements in the laboratory can serve as a model for our understanding of the processes of formation of wood.

Keywords: Iris sibirica L., regenerated plants, lignin, xylem, tracheal elements, hydrocity, intact plants.

\section{References}

1. Turner J.A., Buongiorno J., Maplesden F., Zhu S., Bates S., Li R. Forest Research Bulletin, 2006, vol. 230, pp. 2005-2030.

2. Turner S., Gallois P., Brown D. Annu. Rev. Plant Biol., 2007, vol. 58, pp. 407-433.

3. Fukuda H. Encyclopedia of Life Sciences, 2010, pp. 1-5.

4. Bollhöner B., Prestele J., Tuominen H. Journal of Experimental Botany, 2012, vol. 63, no. 3, pp. 1081-1094.

5. Oda Y., Fukuda H. Current Opinion in Plant Biology, 2012, vol. 15, no. 1, pp. 38-44.

6. Antonova G.F., Zheleznichenko T.V., Stasova V.V. Cibirskii lesnoi zhurnal, 2014, no. 6, pp. 46-59. (in Russ.).

7. Preeti Dahiya. Trends in Plant Science, 2003, vol. 8, pp. 462-465.

8. Pesquet E., Ranocha P., Legay S., Digonnet C., Barbier O., Pichon M., Goffner D. Plant physiol., 2005, vol. 139, pp.1821-1839.

9. Oda Y., Hasezawa S. Plant Tissue Cult., 2006, vol. 119, no. 3, pp. 167-177.

10. Pyo H., Demura T., Fukuda H. Plant J., 2007, vol. 51, no. 6, pp. 955-965.

11. Ibañes M., Fàbregas N., Chory J., Caño-Delgado A.I. Proc. Natl. Acad. Sci. USA, 2009, vol. 106, no. 32, pp. 13630-13635.

12. Kwon S.I., Cho H.J., Park O.K. Autophagy., 2010, vol. 6, no. 8, pp. 1187-1189.

13. Kwon S.I., Cho H.J., Jung J.H., Yoshimoto K., Shirasu K., Park O.K. Plant J., 2010, vol. 64, no. 1, pp. 151-164.

14. Fàbregas N., Ibañes M., Caño-Delgado A.I. Plant Signal Behav., 2010, vol. 5, no. 7, pp. 903-906.

15. Milioni D., Sado P.E., Stacey N.J., Roberts K., McCann M.C. Plant Cell., 2002, vol. 14, no. 11, pp. $2813-2824$.

16. Demura T., Tashiro G., Horiguchi G., Kishimoto N., Kubo M., Matsuoka N., Minami A., Nagata-Hiwatashi M., Nakamura K., Okamura Y., Sassa M., Suzuki S., Yazaki J., Kikuchi S., Fukuda H. Proceedings of the National Academy of Sciences of the United States of America, 2002, vol. 99, no. 24, pp. 15794-15799.

17. Möller R., Koch G., Nanayakkara B., Schmitt U. Tree Physiology, 2005, vol. 26, no. 2, pp. 201-210.

18. Kubo M., Udagawa M., Nishikubo N., Horiguchi G., Yamaguchi M., Ito J., Mimura T., Fukuda H., Demura T. Genes Dev., 2005, vol. 19, pp. 1855-1860.

19. Devillard C., Walter C. New Zealand Journal of Forestry Science, 2014, vol. 44, pp. 2-14.

20. Fukuda H. Annual Review of Plant Physiology and Plant Molecular Biology, 1996, vol. 47, no. 1, pp. $299-325$.

21. McCann M.C. Trends in Plant Science, 1997, vol. 2, no. 9, pp. 333-338.

22. Denton D., Nicolson S., Kumar S. Cell Death and Differentiation, 2012, vol. 19, no. 1. pp. 87-95.

23. Kuriyama H., Fukuda H. Current Opinion in Plant Biology, 2002, vol. 5, no. 6, pp. 568-573.

24. McCabe P.F., Leaver C.J. Plant Molecular Biology, 2000, vol. 44, no. 3, pp. 359-368.

25. Fukuda, H. Nature Reviews Molecular Cell Biology, 2004, vol. 5, no. 5, pp. 379-391.

26. Kohlenbach H.W., Schöpke C. Naturwissenschaften, 1981, vol. 68, pp. 576-577.

27. Roberts A.V., Walker S., Horan I., Smith E.F., Mottley J. Acta Hortic., 1992, vol. 319, pp. 153-158.

28. Lacayo C.I., Malkin A.J., Holman H.Y.N., Chen L., Ding S.Y., Hwang M.S., Thelen M.P. Plant Physiology, 2010 , vol. 154, no. 1, pp. 121-133.

29. Höfte H. Current Biology, 2010, vol. 20, no. 1, pp. 450-452.

30. Bazarnova N.G., Il'icheva T.N., Tikhomirova L.I., Sinitsyna A.A. Khimiia rastitel'nogo syr'ia, 2016, no. 3, pp. $49-57$. (in Russ.).

31. Tikhomirova L.I., Il'icheva T.N., Bazarnova N.G., Sysoeva A.V. Khimiia rastitel'nogo syr'ia, 2016, no. 3, pp. $59-66$. (in Russ.).

32. Bazarnova N.G., Tikhomirova L.I., Frolova N.S., Mikushina I.V. Khimiia rastitel'nogo syr'ia, 2016, no. 1, pp. 43-51. (in Russ.).

33. Obolenskaia A.V. Laboratornye raboty po khimii drevesiny i tselliulozy: uchebnoe posobie. [Laboratory work on the chemistry of wood and cellulose: a tutorial]. Moscow, 1991, 320 p. (in Russ.).

\footnotetext{
* Corresponding author.
} 
34. Muzychkina R.A. Korul'kin D.Iu., Abilov Zh.A. Tekhnologiia proizvodstva i analiz fitopreparatov. [Technology of production of herbal remedies and analysis]. Almaty, 2011, 360 p. (in Russ.).

35. Kalinin F.L., Sarnatskaia V.V., Polishchuk V.E. Metody kul'tury v fiziologii i biokhimii rastenii. [Culture Methods in Plant Physiology and Biochemistry]. Kiev, 1980. 488 p. (in Russ.).

36. Murashige T., Skoog F. Physiol. Plant, 1962, vol. 15, no. 4, pp. 473.

37. Barykina R.P., Veselova T.D., Deviatov A.G. Spravochnik po botanicheskoi mikrotekhnike. Osnovy i metody. [Reference botanical microtechnology. Fundamentals and Methods]. Moscow, 2004, 312 p. (in Russ.).

38. Dzhensen U. Botanicheskaia gistokhimiia. [Botanical histochemistry]. Moscow, 1965, 377 p. (in Russ.).

39. Kletochnaia obolochka rastitel'noi kletki. [The cell wall of the plant cell]. [Elektronnyi resurs]. URL: http://www.activestudy.info/kletochnaya-obolochka-rastitelnoj-kletki/.(in Russ.).

40. Shanidze M.A. Anatomicheskii analiz vegetativnykh organov gruzinskikh predstavitelei roda Iris kak materi-al dlia poznaniia filogeneza roda : avtoref. dis. ... kand. biol. nauk. [The anatomical analysis of vegetative organs of Georgian representatives of the genus Iris as a material for the knowledge of phylogeny of the genus: Abstract. Dis. ... Cand. biol. Sciences]. Tbilisi, 1955, 25 p. (in Russ.).

41. Esau K. Anatomiia rastenii. [Plant anatomy]. Moscow, 1969, 564 p. (in Russ.).

42. Churikova O.A. Biotekhnologiia kak instrument sokhraneniia bioraznoobraziia rastitel'nogo mira. Sbornik statei po materialam II Vserossiiskoi nauchno-prakticheskoi konferentsii. [Biotechnology as a tool for conservation of flora biodiversity. Collection of articles on materials of II All-Russian scientific-practical conference]. Volgograd, 2008, pp. 276-282. (in Russ.).

43. Razdorskii V.F. Arkhitektonika rastenii. [Plant Arhitektonika]. Moscow, 1955, 402 p. (in Russ.).

44. Aleksandrov V.G. Anatomiia rastenii. [Plant anatomy]. Moscow, 1966, 431 p. (in Russ.).

45. Roberts L.W. Bot. Rev., 1969, vol. 35, no. 3, pp. 201-250.

46. Wagner A., Donaldson L., Ralph J. Advances in Botanical Research, 2012, vol. 61, pp. 37-76.

47. Roberts K., McCann M.C. Current Opinion in Plant Biology, 2000, vol. 3, no. 6, pp. 517-522.

Received October 10, 2016

Revised December 1, 2016 
